\title{
TACTICS OF ATTACK OF FOOTBALL TEAMS IN THE CHAMPIONS LEAGUE KNOCKOUT PHASE IN SEASONS OF 2015/2016 AND 2016/2017
}

\author{
Bojan Leontijević, Aleksandar Janković, Lazar Tomić \\ University of Belgrade, Faculty of Sport and Physical Education, Serbia
}

\begin{abstract}
The aim of this study is to find out characteristics of tactics of attack of teams which play in the finals of the Champions Leagule by analyzing competition activities and also to use comparative analysis for the same competition in two competition seasons and point to the potential tendencies in tactical preparation of teams for the very end of the competition. The analysis involved quarter-finals, semi-finals and finals in seasons 2015/2016 and 2016/2017, i.e. 13 matches in each season. The tactical action was analyzed by monitoring variables that describe the ways of beginning, realization and completion of successful attacks, but also the overall characteristics of play when a team was in ball possession (scope, success and speed of passing the ball). Results of this study showed that that there are no significant differences in tactical demonstration of teams that play the final round of the competition in two competition seasons. The application of continuous attacks is dominant, beginning by cutting a pass and winning "the second ball" on the opponent's half, while the final pass is in most cases the centre and back lateral passing. However, significand difference was discovered only in efficiency during the passing game, which was significantly greater in the 2016/2017 season ( $\mathrm{p}=0.013$ ) and partially in the longer ball possession also in the 2016/2017 season. The kind of analysis in the field of foodball tactics is valuable because it provides a possibility to define the criteria for achieving results on the highest level, but to predict potential tendencies in developing offensive foodball tactics.
\end{abstract}

Key words: FOOTBALL / COMPETITION ACTIVITY / GAME ANALYSIS / SUCCESSFUL ATTACKS / PASSING GAME

\section{INTRODUCTION}

Moments of the game that more or less influence the final result can be identified by analyzing competition activities in football on the individual or the team level (Castelano et al., 2012; Liu \& Gomez., 2014; Liu et al., 2015a). Studies that deal with this kind of analyses in a longer period of time aim at discovering these technical and tactical parameters of the game correlated with success, and, on the other hand, serve to envisage new trends, and above all, football game tactics (McGarry et al., 2002). Results of these studies and their explanation function to define theoretical procedures in evolutive development of football, but they also have a significant role in technological process and preparation for certain football competitions.

A high level of technical, tactical, physical and psychological preparation is a necessary prerequi- site for competition on the highest level. The training process for each of the types of preparation, through evolution of the football game has been changing and adapting according to demands and characteristics of the same game. Evolution of the foodball game is moving towards the intensified activities of players with and without the ball that directly influence the group and team actions in certain standard situations of the game (Wallace \& Norton, 2014). Significantly higher scope and intensity of movement of players during the game, and on the other hand, reduction of time of the active play are indicators of changes in demands of players necessary for competition on the elite level. Besides, significantly greater closeness of players on the area but also the speed of movement of the ball on the pitch point to changes in organization of the game on the group and the team level (Wallace \& Norton, 2014). 
One of the most systematic overviews of methods of football game analysis was presented by Sarmento et al. (2014), who divided the research activity in football into descriptive, comparative and predictive analysis. The space of description is related to the description of technical, tactical and physical performances of a football player; the comparative analysis mostly take into consideration the level/type of the competition and position of a player in a team, while the prediction of actions based on the already seen is a space in which standard protocols are defined. For all types of analyses, towards determining characteristics of offensive tactics, the structure of attack actions that ended with the shot on the opponent's goal was observed (Lago - Penas et al., 2010; Castellano et al., 2012; Mitrotasios \& Armatas, 2014; Liu et al., $2015 \mathrm{~b}$ ) but also the quality of the passing game and the way of realization of some standard situatios like breaks of the game, offensive transitions and the like (Janković et al., 2009; Almeida et al., 2014; Liu et al., 2015b; Janković et al., 2016).

Based on the current directions in the football game analysis, a need arose to continuously monitor tactical manifestation at the highest quality competitions of modern football in order to accurately define directions of the game development from the tactical prospective, but also to identify those technical and tactical elements of the game that can be characterized as the coach's surprise for a certain match.

Therefore, the object of this research was the highest quality club competition in football, the Champions League, in two succesive seasons of competition, that is, the tactics of attack of teams which played in the finals. The specificity is the fact that the FC Real Madrid was the winner of the competition in both seasons, so it was interesting to see whether and to what extent Real and other teams changed their tactical plan of the game.

Thus, the aim of this paper was to determine characteristics, as well as to define modern tendencies in relation to the tactics of the attack of teams that compete on the highest level, in this case in the Champions League. Based on the results of studies completed so far, it was expected that certain characteristics of the offensive tactics specific for the competition itself would be sorted out, but also that parameters of the game related to individual preparation, the idea of the coach, specificity of teams that have qualified for the finals of the competition etc. would be discovered.

\section{METHOD}

\section{Research sample}

The sample of matches that were analyzed for needs of this study included the final matches of the Champions League (CL) in seasons 2015/16 and 2016/17. Matches played in quarter-finals, semi-finals and finals were observed, i.e. 13 matches of this competition for each season, therefore the total of 26 matches were analyzed.

\section{Sample of variables and ways of data collection}

Since the result represents the basic measure of success in football, which is the consequence of successfully completed attack actions of a team, to describe the tactics of attack, variables that point to the structure of successful attacks were observed (all offensive actions were finished by the shoot on the opponent's goal):

- Number of shots on the goal (successful attacks);

- Accuracy of successful attacks - inacurrate, accurate and efficient;

- Time interval of realization: 0 - 15 minutes, 15 30 min., 30 - 45 min., 45 - 60 min., 60 - 75 min., 75 - $90 \mathrm{~min}$. and $90-120 \mathrm{~min}$;

- Zone of initiation of successful attacks - attacks started from the defence, middle or attack zone;

- The way the successful attacks started - "cutting the ball", winning the tackle, throw-in (the attack that started by throwing the ball in), free kick play (the attack started after the free kick, and the ball was not directed to the opponent's penalty area), "the second ball" (coming into possession after "winning" the ball that had never been in control by either team), offensive stoppage and attacks started by the goalkeeper's pass;

- Types of successful attacks - continuous, counter-attacks and set pieces attacks;

- Structure of successful attacks - number of participant players, number of passes, duration of an attack;

- The way of coming into position for the shot on the goal (assistance) - individual attack, "the second ball", centre, back pass, long pass;

- Zones from which shots on the goal were directed - 0 - $5 \mathrm{~m}, 5-11 \mathrm{~m}, 11-16 \mathrm{~m}$ and $>16 \mathrm{~m}$;

- The segment with which the shot was made head, left leg, right leg. 
Together with successful attacks, towards defining the attacking tactics, variables that point to the orientation of the game in situations when the team was in ball possession were monitored:

- Total duration of the ball possession during the match, number of ball possession situations, duration of ball possession;

- Number of successful passes, percentage of successful passes, the speed of passes (number of precise passes in the unit of time by the achieved possession of the ball).

The analysis of previously recorded matches started with creation of the observing protocol (Carling et al., 2005). That protocol was used for each match and each team separately. While observing matches, each successful attactk and action that ended with the shot on the goal was recorded in the observation sheet. Video materials were taken from the TV channels Premium sport - HD, Bein sports - HD, Sky sports HD, and Premium Calco - HD.

\section{Data processing}

Each variable was processed by standard descriptive statistics (total and mean value, as well as standard deviation). Differences in distribution of certain tactical indicators within one group between com- petition seasons 2015/2016 and 2016/2017 were assessed by nonparametric chi-square test, while for examining differences between two independent competitions the Mann-Whitney $U$ test was used in certan variables. The level of statistical significance was $p<0.05$. All statistical tests were processed using SPSS 17.0 program (SPSS INC Chicago, IL).

\section{RESULTS}

Results of this study have shown that teams that appeared in the finals of the competition in the 2016/2017 season were slightly more offensive, which was confirmed by the data according to which the average number of successful attacks was $11.5 \mathrm{com}$ pared to the previous season - 9.5. The ratio of inacurrate, accurate and efficient shoots towards the goal was $48 \%-41 \%-11 \%$ in the $2015 / 2016$ season, and $49 \%-38 \%-13 \%$ in the $2016 / 2017$ season.

Observing successful attacks realized in certain time intervals, it can be noted that the number of such attacks in seasons 2015/16 and 2016/17 was equal, however, in the 2016/2017 season more attacks were realized in the introductory parts of the first and the second halftime (Figure 1).

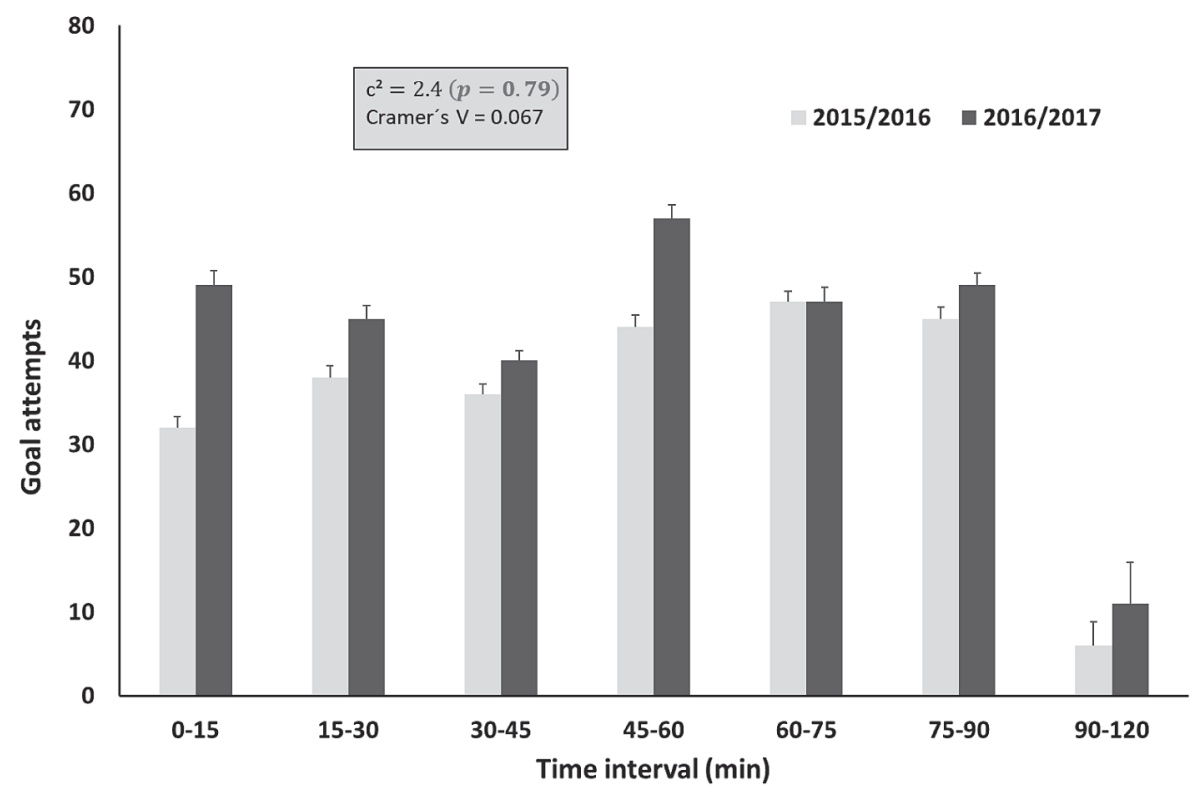

Figure 1. Number of successful attacks in relation to time intervals of the duration of the game in the competition of the Champions League (seasons 2015/16 and 2016/17)

When the type of the attack is in question, the analysis showed that the application of continuous attacks, counter attacks and successful actions after the break of the game is proportionally represented in both seasons (Table 1). Somewhat smaller percentage of shots to the goal after the break in the season 
2016/17 was manifested through the increase in the number of successful attacks from the game (continuous attacks and counter attacks). The largest number of shots on the goal occurred after organization of continuous attacks, and the fact in connection with this data is the average duration of successful attacks that was 13.9 seconds in the $2015 / 16$ season, and 13.57 seconds in the second competition season (Table 2).
The teams most often started successful attacks in both competition seasons from the attacking third of the pitch, then from the middle zone, and the least number of successful actions started from the defence zone (Table 1). Besides, the analysis shows that in the second season (2016/2017) the number of attacks started from the attacking third is slightly larger compared to the first season $(46 \%$ - $49 \%)$ while on the other hand fewer attacks started from the middle zone (36\% - 32\%).

\begin{tabular}{|c|c|c|c|c|c|}
\hline \multirow{2}{*}{ Zone of initiation } & \multicolumn{2}{|c|}{$2015 / 2016$} & \multicolumn{2}{|c|}{$2016 / 2017$} & \multirow{2}{*}{ Chi Square } \\
\hline & Total & $\%$ & Total & $\%$ & \\
\hline Defense zone & 45 & 18 & 56 & 19 & $c^{2}=0.996$ \\
\hline Middle zone & 89 & 36 & 95 & 32 & $p=608$ \\
\hline Attack zone & 114 & 46 & 147 & 49 & Cramer's V $=0.43$ \\
\hline \multicolumn{6}{|l|}{ Types of attack } \\
\hline Continuous & 138 & 56 & 173 & 58 & $c^{2}=1.320$ \\
\hline Counter attack & 58 & 23 & 74 & 25 & $p=0.517$ \\
\hline Set play & 52 & 21 & 51 & 17 & Cramer's V $=0.049$ \\
\hline \multicolumn{6}{|l|}{ Attemts zone $(\mathrm{m})$} \\
\hline $0-5$ & 18 & 7 & 18 & 6 & $c^{2}=1.711$ \\
\hline $5-11$ & 87 & 35 & 119 & 40 & $p=635$ \\
\hline $11-16$ & 39 & 16 & 48 & 16 & Cramer's V $=0.056$ \\
\hline $16>$ & 103 & 42 & 113 & 38 & \\
\hline \multicolumn{6}{|l|}{ Goal atempts } \\
\hline Head & 50 & 20 & 58 & 19 & $c^{2}=0.101$ \\
\hline Left leg & 84 & 34 & 98 & 33 & $p=0.96$ \\
\hline Right leg & 114 & 46 & 142 & 48 & Cramer's V $=0.014$ \\
\hline
\end{tabular}

Table 1. Zones from which successful actions were initiated, types of realized successful attacks, zones of direction and segments used to shoot on the goal in the Champions League (seasons 2015/16 and 2016/17)

Results show that shots on goal in both seasons most rarely came from zones $0-5 \mathrm{~m}$ and $11-16 \mathrm{~m}$, as well as that players in the observed matches most often shot from the $5-11 \mathrm{~m}$ zone and the area $>16 \mathrm{~m}$ (Table 1). However, in the $2015 / 16$ season, the percentage of realized shots from the $5-11 \mathrm{~m}$ zone was smaller than from the area $>16 \mathrm{~m}$, while in the season of 2016/17 the number of shots from the $5-11 \mathrm{~m}$ zone was larger compared to shots outside the 16-meter area. Shots performed with a leg were dominant, in most cases the shot was realized using right leg $(46 \%-48 \%)$, then left leg $(34 \%-33 \%)$ and finaly using head (20\% - 19\%) (Table 1).

Winning "the second ball" and cutting the ball are the most often used forms to start a successful attack, and the significant number of actions that ended with a shot towards the goal started after organizing an offensive break (Figure 2).

The analysis of the attack structure, observed according to the number of players who participated and the number of passes during a successful ac- tion showed that in both seasons teams performed successful attacks with $3-5$ players, at which most often there were 4 passes before a shot on the goal (Table 2).

The total duration of possession of the ball in one game was slightly longer in the 2016/17 season and the difference is 45 seconds per a match, besides, the teams were in ball possession slightly longer in the second season, in average 16.8 seconds (Table 2).

The dynamics of the play in both seasons was equal, which was confirmed by the results of the speed of passes, but the teams in the second season were more successful in passing the ball from one player to another (Table 2).

Results further show that the end of successful attacks was mostly different after assistences of centre shots, then after individual actions, long passes, back passes and finally after "the second ball" won. Together with the listed, a significant increase in the case of assistences with centre shots and back passes in the second season is also interested (Figure 3). 


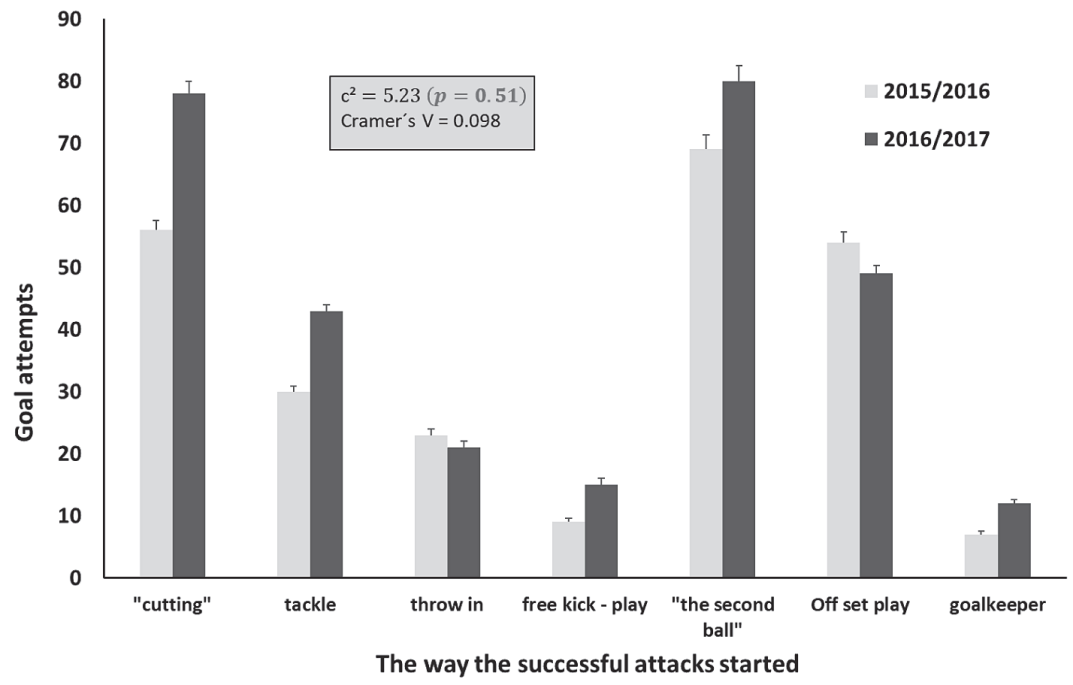

Figure 2. Ways to initiate successful attacks in the Champions League (seasons 2015/16 and 2016/17)

Table 2. Structure of successful attacks, ball possession and passing game in the Champions League seasons 2015/16 and 2016/17)

\begin{tabular}{|c|c|c|c|c|c|}
\hline \multirow{2}{*}{ Goall atempts } & \multicolumn{2}{|c|}{$2015 / 2016$} & \multicolumn{2}{|c|}{$2016 / 2017$} & \multirow{2}{*}{$U$ test } \\
\hline & Mean & Stdev & Mean & Stdev & \\
\hline Number of players & 4.22 & 1.14 & 4.01 & 1.01 & $p=0.406$ \\
\hline Number of passes & 4.62 & 2.15 & 4.23 & 1.61 & $p=0.510$ \\
\hline Duration of attack & 13.9 & 5.89 & 13.57 & 4.17 & $p=0.869$ \\
\hline \multicolumn{6}{|l|}{ Ball possesion } \\
\hline Total duration of possesion (min) & 29.47 & 0.18 & 30.32 & 0.14 & $p=0.071$ \\
\hline Number of possesions & 109 & 6.34 & 109.8 & 7.55 & $p=0.828$ \\
\hline Possesion duration (sec) & 16.5 & 2.57 & 16.8 & 2.24 & $p=0.433$ \\
\hline \multicolumn{6}{|l|}{ Passes } \\
\hline Successful passes & 471 & 92.5 & 479 & 70.78 & $p=0.337$ \\
\hline Successful passes (\%) & 84 & 2.8 & 86 & 2.3 & $p=0.013$ \\
\hline Speed of passes & 16 & 1.02 & 16 & 0.86 & $p=0.804$ \\
\hline
\end{tabular}

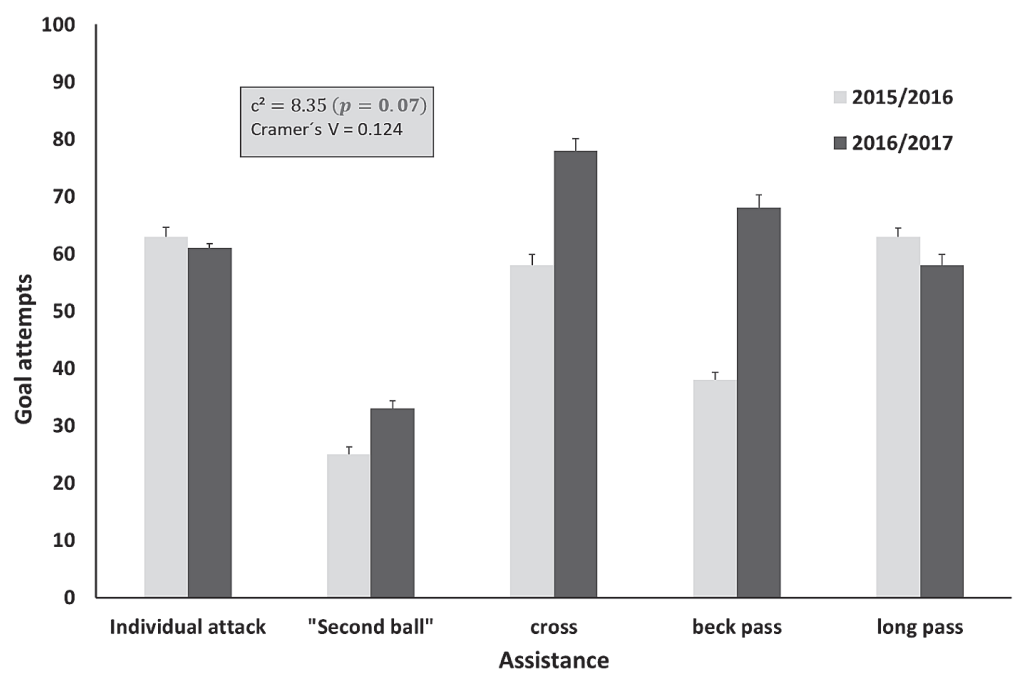

Figure 3. The number of successful actions in relation to the way of coming into the position to shoot on the goal in the Champions League (seasons 2015/16 and 2016/17) 


\section{DISCUSSION}

Results of this study showed that the finals of the Champions League demand a certain level of technical and tactical manifestation, taking into account the fact that there are no significan differences in the structure of successful attacks of teams that ranked into the quarter-finals of this competition in two competition seasons. However, certain technical and tactical elements of play sorted out which are different to a certain extent and in that way they point to certain innovations in preparations of teams for the finals of the competition.

Realization of successful attacks in relation to time intervals of duration showed that there are no differences in the dynamics of the play between two competition seasons, however, it is noted that in the first 15 miniutes of both half terms there were more active periods in the 2016/2017 season. Both seasons are characterized by a larger number of shots on goal in the second half-time, which is generally the case in other competititons (Sgro et al., 2015; Liu et al., 2016), but it is interesting that in the second season there was the largest number of shots on goal exactly in the introductory part of the game, which can be linked to the data according to which in $70.9 \%$ of cases the first team that scored the goal won the match (Michaildis et al., 2013).

According to some analyses, getting in possession of the ball way deep on the opponent's half of the pitch is one of the factors that directly attects the success in modern football (Mackenzie \& Cushion, 2013; Almeida et al., 2014; Janković et al., 2016). The results of this study showed that the teams which differentiated by their quality and ranked in the finals of this competition tend to apply pressing in order to take possession of the ball from the opponent as close to the opponent's goal as possible and thus attack the distraught defense of the opponent. A slightly higher percentage of attacks started from the attacking third of the pitch in the 2016/2017 season which, among other things, influenced greater efficiency of successful attacks compared to the 2015/2016 season.

Application of continuous attack, according to results of this study, represents a dominant form of offensive action organization. If we take into account the data according to which is directy linked with the positive result (Leontijević et al., 2015), it can be said that for ranking in the finals of the competition a tactical commitment in the play according to which passing game and ball possession resulted in the shot on the opponent's goal. For such a tactical plan it is necessary to have players who are firstly technically skilled for such way of playing a game. Thus, teams that base their offensive actions exclusively on a direct play (counter attack) or rely on a break cannot achieve good results continuously. However, such a statement can be further examined in some future studies if we take into account the fact that these matches are eliminatory, and, at the same time, their importance is significantly greater, the play itself is more cautious, teams tend to risk less, primarily trying to score a goal, they lose ball possession less frequently in the phase of the initiation of the attack, etc.

The quality in the game by applying the continous attack, among other things, can be analysed by efficiency in the ball possession manifested through the success in passing the ball. The 2016/2017 competition season was more efficient in relation to the previous one (a larger number of goals), probably contributed by the data according to which the teams were in ball possession for 45 seconds longer during the match. Besides, the second season is characterized by significantly greater success in passing game $(\mathrm{p}=0.013)$, while the speed of the ball during passing was equal. Thus, the conclusion is imposed that it is necessary to technically prepare a player for a game as for the successful passing the ball and for playing under pressure in order to achieve results in football at the highest level. Results of the study that analyzed competitions on the different level (national leagues) also showed that the duration of ball possession, successfulness in passing game and the speed of the ball during passes are the basic indicators of success (Bekris \& Gioldasis, 2014; Leontijević et al., 2015; Barreira et al., 2016)

Ball possession nearer to the opponent's goal, application of cutting the ball and winning "the second ball" during the start of actions that end in shot on the goal, suggest the application of pressing at the very beginning of the opponent's attack which was slightly more often applied in 2016/2017 competition season. Moreover, the distance of the shot is a data which is correlated with the positive result and the efficiency of the shot itself (Michailidis et al., 2013; Liu et al., $2015 b$ ), so that a slightly larger number of shots from the 5 - 11-meter zone in the 2016/2017 season resulted in larger number of scored goals. However, there is an interesting data according to which there are more and more shots on the goal after lateral passes (centre) and back passes, having in mind the data ac- 
cording to which the number of centre shots during a match negatively correlatew with the success in the game (Liu et al., 2015b; Liu et al., 2016).

\section{CONCLUSION}

The analysis of the finals of the Champions League in seasons 2015/2016 and 2016/2017 showed that there is no clearly defined structure of attacking actions that end with a shot on goal for this level of competition. The application of continuous attacks, a high percentage of success in the passing game with the distribution of the ball, especially in the attacking third of the pitch represent dominanat forms of realization of successful attacks. Also, it can be concluded, based on some differences, that there is an increasing tendency in the offensive tactics to play through the wing positions, to employ the players of impeccable technical skill which increases accuracy in ball passing, and affects efficiency of the final pass and the shot on goal. Besides, there is an increase in number of attacks inititated in the attacking third of the pitch, that is, the application of high-pressing at the beginning of the opponent's attack which has become more frequent choice in the defensive orgranization.

\section{REFERENCES:}

1. Almeida, C.H., Ferreira, A.P., \& Volossovitch, A. (2014). Effects of match location, match status and quality of opposition on reagaining possession in UEFA Champions League. Journal of Human Kinetics, 41(1), $203-214$.

2. Barreira, J., Vendite., C., \& Vendite L.L. (2016). Analysis of shots and passing sequence of a soccer team and its opponents during 2014 Brazilian Championship. International Journal of Sports Science, 6(4), 163 - 167.

3. Bekris, E., \& Gioldasis, A. (2014). Winners and losers in top level soccer. How do they differ? Journal of Physical Education and Sport, 14(3), 398 - 405.

4. Carling, C., Williams, A.M., Reilly, T. (2005). Handbook of soccer matches analysis. A systematic approach to improving performance. Routledge, London.

5. Castellano, J., Casamichana, D., \& Lago, C. (2012). The use of match statistics that discriminate between successful and unsuccessful soccer teams. Journal of Human Kinetics, 31, 139 - 147.
To provide a more detailed analysis and more precise discovering of the game mechanisms, it is necessary to examine the structure of continuous attacks, counter attacks and set pieces in the future studies. Also, using comparative analysis, elimination matches and the group phase of the competition, it is necessary to examine whether and to which extent the importance of the game affects the tactical plan of the game. Of course, the analysis of each subsequent competition season will only determine certain standards in the offensive tactics of football on the highest level, but also point to the actual tendencies of development and improvement.

The value of this kind of analysis in the field of football tactics is reflected in clear directions when it comes to preparation of a foodball team which tends to be highly ranked in the Champions League. Therefore, necessary parameters of the game have been defined precisely, i.e. criterion of demands for the highest level of competition have been determined. On the other hand, theoretical value of such an approach in analysing competitive activity in football is the definition of current demands in the football tactics on the highest level and prediction of potential tendencies of development in the forthcoming period.

6. Janković, A., Leontijević, B., Mićović, B. (2009). Tendencije razvoja taktike igre kroz analizu uspešnih napada na XVI, XVII i XVIII svetskom prvenstvu u fudbalu [Trends in development of tactics through analysis of successful attacks on the XVI, XVII and XVIII World Cup]. In Koprivica V. and Juhas I. (eds.). Proccedings from international conference: The teoretical, methodological and methodical aspects of competitions and athletes preparation, $(115$ - 120). Beograd: FSFV.

7. Janković, A., Leontijević, B., Tomić, L. (2016). Attacks of the soccer teams participationg in the Champions League and the Serbian Super League. Physical culture, 70(1), 80 - 87.

8. Lago - Penas, C., Lago - Ballesteros, J., Dellal, A. \& Gomez, M. (2010). Game - related statistics that discriminated winning, drawing and losing teams from the Spanish soccer league. Journal of Sports Science and Medicine, 9, 288 - 293.

9. Leontijević, B., Janković, A, \& Ćosić, N. (2015). Uporedna analiza taktičkog ispoljavanja fudbalera 
Partizana na utakmicama u evropskim takmičenjima i Super ligi Srbije [Comparative analysis of tactical manifestation of Partizan players to matches in European competitions and the Super League Serbia]. In Kasum G. and Mudrić M. (eds.). Conference proceedings at: The effects of physical activity application to anthropological status of children, youth and addults, (pp. 443 - 450). Beograd: FSFV

10. Liu, H., Gomez, M.A. (2014). Relationships between match performance indicators and match outcome in 2014 Brazil FIFA World Cup. Conference: VIII Congreso Internacional de la Asociacion Espanola de Ciencias del Deporte. Spain.

11. Liu, H., Yi, Q., Gimenez, J.V., Gomez, M.A., \& Lago - Penas, C. (2015a). Performance profiles of football teams in the UEFA Champions League considering situational efficiency. International Jorunal of Performance Analysis in Sport, 15, 371 - 390.

12. Liu. H., Gomez., M.A., Lago - Penas, C., \& Sampaio, J. (2015b). Match statistics related to winning in the group stage of 2014 Brazil FIFA World Cup. Journal of Sports Sciences, 33(12), 1205 - 1213.

13. Liu, H., Gomez, M.A., Goncalves, B., \& Sampaio, J. (2016). Tehnical performance and match to match variation in elite football teams. Journal of Sports Sciences, 34(6), 509 - 518.

14. Mackenzie, R., Cushion, C. (2013). Performance analysis in football: A critical review and implica- tions for future research. Journal of Sports Sciences, 31(3), 639 - 676.

15. McGarry, T., Anderson, D. I., Wallace, S. A., Hughes, M. D., \& Franks, I. M. (2002). Sport competition as a dynamical selforganizing system. Journal of Sports Sciences, 20(10), 771 - 781.

16. Michaildis, Y., Michaildis, C., Primpa, E. (2013). Analysis of goals scored in European Championship 2012. Journal of Human Sport \& Exercise, 8(2), $367-375$.

17. Mitrotasios, M., \& Armatas, V. (2014). Analysis of goal scoring patterns in the 2012 European Football Championship. The Sport Journal. Available at http://thesportjournal.org/article/analysis-of-goal-scoring-patterns-in-the-2012-european-football-championship/.

18. Sarmento, H., Marcelino, R., Anguera, M. T., Campanico, J., Matos, N., \& Leitao, J. C. (2014). Match analysis in football: A systematic rewiew. Journal of Sports Sciences, 32(20), 1831 - 1843.

19. Sgro, F., Barresi, M., \& Lipoma, M. (2015). The analysis of discriminant factors related to team match performance in the 2012 European Football Championship. Journal of Physical Education and Sport, 15(3), 460 - 467.

20. Wallace, J.K., \& Norton, K.I. (2014). Evolution of World Cup soccer final games 1966 - 2010. Journal of Science and Medicine in Sport, 17(2), 223 - 228.

\title{
ANGRIFFSTAKTIK VON FUßBALLMANNSCHAFTEN IN DER ENDPHASE DER CHAMPIONS-LEAGUE IN DEN SAISONS 2015/2016 UND 2016/2017
}

\begin{abstract}
Zusammenfassung
Ziel dieser Arbeit ist es, durch eine Analyse der Wettbewerbsaktivitäten Charakteristiken der Angriffstechnik von Teams zu entdecken, die in der Endphase der Champions-League spielen, sowie durch eine parallelle Analyse der gleichen Meisterschaft in zwei Wettbewerbssaisons auf eventuelle Tendenzen in der Taktikvorbereitung für die Endphase der Meisterschaft hinzuweisen. Die Analyse umfasste das Viertelfinale, Halbfinale und die Finalspiele in den Saisons 2015/2016 und 2016/2017, also je 13 Fußballspiele in beiden Saisons. Das taktische Vorgehen wurde durch Verfolgung von Variablen analysiert, die Beginn, Realisierung und Abschluss von erfolgreichen Angriffen beschreiben, aber auch der insgesamten Charakteristiken des Spiels, wenn das Team im Besitz des Balls ist (Umfang, Erfolg und Geschwindigkeit im Zuspielen des Balles). Die Ergebnisse dieser Untersuchung weisen darauf hin, dass es keine bedeutenden Unterschiede in der taktischen Vorgehensweise der Teams gibt, die in der Endphase der Meisterschaft in zwei Wettbewerbssaisons spielen. Es dominiert die Anwendung von kontinuierlichen Angriffen, die mit Abschneiden und Eroberung des „Zweiten Balles“ in der gegnerischen Spielhälfte begonnen werden; das finale Zuspielen bezieht sich in größtem Maße auf Flankenstoß oder Rückpass aus seitlichen Positionen. Ein bedeutender Unterschied wurde nur in der Effizienz beim Passspiel entdeckt, der bedeutend größer in der Saison 2016/2017 (p=0.013) war und teilweise im längeren Ballbesitz ebenfalls in der Saison 2016/2017. Der Wert dieser Art von Analyse aus dem Bereich der Fußballtaktik spiegelt sich in der Definierung der Kriterien für die Erzielung von Ergebnissen auf höchster Ebene, aber auch in der Prädiktion eventueller Tendenzen in der Entwicklung von offensiven Fußballtaktiken.
\end{abstract}

Schlüsselwörter: FUßBALL / WETTBEWERBSAKTIVITÄT / SPIELANALYSE / ERFOLGREICHE ANGRIFFE / PASSSPIEL

Received: 25.09 .2017

Accepted: 15.11.2017 


\title{
ТАКТИКА НАПАДА ФУДБАЛСКИХ ТИМОВА У ЗАВРШНИЦИ ТАКМИЧЕЊА ЛИГЕ ШАМПИОНА У СЕЗОНАМА 2015/2016 и 2016/2017
}

\author{
Бојан Леонтијевић, Александар Јанковић, Лазар Томић \\ Универзитет у Београду, Факултет спорта и физичког васпитања
}

\begin{abstract}
Сажетак
Циљ овог истраживања је да се, анализом такмичарске активности, открију карактеристике тактике напада екипа које играју у завршници такмичења Лиге шампиона, као и да се упоредном анализом, истог такмичења у две такмичарске сезоне, укаже на евентуалне тенденције у тактичкој припреми тимова за саму завршницу такмичења. Анализом су обухваћене четвртфиналне, полуфиналне и финалне утакмице у сезонама 2015/2016 и 2016/2017, дакле по 13 утакмица у обе сезоне. Тактичко деловање анализирано је праћењем варијабли које описују начин почетка, реализације и завршнице успешних напада али и свеукупне карактеристике игре када је екипа у поседу лопте (обим, успешност и брзина додавања лопте). Резултати овог истраживања показали су да нема значајних разлика у тактичком испољавању тимова који играју завршницу такмичења у две такмичарске сезоне. Доминира примена континуираних напада, започетих пресецањем и освајањем „друге лопте“ на половини противника, а завршно додавање у највећој мери представља центаршут и повратна лопта са бочних позиција. Међутим, значајна разлика откривена је само у ефикасности приликом пас игре, која је била значајно већа у сезони 2016/2017 (p=0.013) и делимично у дужем поседу лопте у корист, такође сезоне 2016/2017. Вредност овакве врсте анализа из простора тактике фудбала огледа се у дефинисању критеријума за остваривање резултата на највишем нивоу, али и предикцији евентуалних тенденција развоја офанзивне тактике фудбала.
\end{abstract}

Кључне речи: ФУДБАЛ / ТАКМИЧАРСКА АКТИВНОСТ / АНАЛИЗА ИГРЕ / УСПЕШНИ НАПАДИ / ПАС ИГРА

\section{УВОД}

Анализом такмичарске активности у фудбалу, на индивидуалном или екипном нивоу, могу се идентификовати они моменти игре који у већој или мањој мери утичу на коначан резултат (Castelano et al., 2012; Liu \& Gomez., 2014; Liu et al., 2015a). Истраживања која се баве оваквим обликом анализа, у дужем временском периоду, имају за циљ да са једне стране открију оне техничко-тактичке параметре игре који су повезани са успехом, и са друге стране буду у функцији предвиђања нових праваца, пре свега, у тактици фудбалске игре (McGarry et al., 2002). Резултати оваквих истраживања и њихова тумачења у функцији су дефинисања теоријских постулата у еволутивном развоју фудбала али имају и значајну улогу у технолошком процесу и припреми за одређена фудбалска такмичења.
Висок ниво техничке, тактичке, физичке и психолошке припремљености представља неопходан предуслов за такмичење на највишем нивоу. Тренажни процес за сваки од наведених видова припреме, кроз еволуцију фудбалске игре мењао се и адаптирао захтевима и карактеристикама саме игре. Еволуција фудбалске игре креће се у правцу интезификације активности играча са и ठез лопте, што директно утиче и на групна и тимска деловања у појединим стандардним ситуацијама игре (Wallace \& Norton, 2014). Значајно већи обим и интезитет кретања играча током утакмице, а са друге стране смањење времена активне игре показатељи су промена у захтевима играча неопходим за такмичење на врхунском нивоу. Поред тога, значајно већа „густина“ играча на простору али и брзина кретања лопте на терену указују на промене у организацији игре на групном и тимском нивоу (Wallace \& Norton, 2014). 
Један од најсистематичнијих прегледа метода анализе фудбалске игре дали су Сарменто и сарадници (2014), према којима се истраживачка активност у фудбалу може поделити на дескриптивну, компаративну и предиктивну анализу. Простор дескрипције везује се за опис техничких, тактичких и физичких перформанси фудбалера, компаративна анализа у највећој мери узима у разматрање ниво/врсту такмичења и позиције играча у тиму, док је предикција дешавања на основу већ виђеног простор у коме се тек дефинишу стандардни протоколи. За све облике анализа, у циљу одређивања карактеристика офанзивне тактике, посматрана је структура нападачких акција које су завршене ударцем на гол противника (Lago - Penas et al., 2010; Castellano et al., 2012; Mitrotasios \& Armatas, 2014; Liu et al., 2015b) али и квалитет пас игре и начин реализације појединих стандардних ситуација као што су прекиди игре, офанзивне транзиције и сл. (Јанковић и сар., 2009; Almeida et al., 2014; Liu et al., 2015b; Јанковић и сар., 2016).

На основу актуелних праваца у анализи фудбалске игре намеће се потреба за континуитетом у праћењу тактичког испољавања најквалитетнијих такмичења савременог фудбала, како би се прецизније дефинисали правци развоја игре у тактичком погледу, али и идентификовали они техничко-тактички елементи игре који се могу окарактерисати као тренерско изненађење за поједину утакмицу.

Према томе, предмет овог рада је најквалитетније клупско такмичење у фудбалу, Лига шампиона у две узастопне такмичарске сезоне, односно тактика напада тимова који су играли саму завршницу. Специфичност је у томе што је фудбалски клуб Реал из Мадрида освајач овог такмичења у обе такмичарске сезоне, па је занимљиво видети да ли, и у којој су мери, и Реал али и остали тимови, свој тактички план игре мењали.

Дакле, циљ овог рада јесте утврђивање карактеристика, као и дефинисање савремених тенденција у односу на тактику напада екипа које се такмиче на највишем нивоу, конкретно у такмичењу Лиге шампиона. На основу резултата досадашњих истраживања очекује се да се издвоје одређене карактеристике офанзивне тактике које су специфичне за само такмичење али и да се открију они параметри игре који су у вези са појединачном припремом, идејом тренера, специфичностима тимова који се пласирају у завршницу такмичења итд.

\section{МЕТОД}

\section{Узорак истраживања}

Узорак утакмица, које су анализиране за потребе овог истраживања су утакмице завршнице такмичења Лиге шампиона (ЛШ) у сезонама 2015/16 и 2016/17. Посматране су утакмице четвртфинала, полуфинала и финала, односно по 13 мечева овог такмичења у обе сезоне, према томе, анализирано је укупно 26 утакмица.

\section{Узорак варијабли и начин прикупљања података}

Како резултат представља основно мерило успешности у фудбалу, који је опет последица успешно изведених нападачких акција једног тима, за описивање тактике напада посматране су варијабле које указују на структуру успешних напада (све офанзивне акције завршене ударцем на гол противника):

- број удараца на гол (успешних напада);

- прецизност успешних напада - непрецизни, прецизни и ефикасни;

- временски интервал реализације: 0 - 15 мин, 15 - 30 мин, 30 - 45 мин, 45 - 60 мин, 60 - 75 мин, 75 - 90 мин и $90-120$ мин;

- зона почетка успешних напада - напади започети из зоне одбране, маневра и напада;

- начин започињања успешних напада - „пресецање“, одузимање, аут-игра (напад започет убацивањем лопте из аута), слободан ударац-игра (напад започет након изведеног слободног ударца, а да притом лопта није упућена директно у казнени простор противника), „друга лопта“ (долазак у посед након „освајања“ лопте која у једном тренутку није била под контролом нити једног тима), офанзиван прекид и напади започети додавањем од стране голмана;

- врста успешних напада - континуирани, контранапади и напади реализовани након прекида игре;

- структура успешних напада - број играча учесника, број додавања, трајање напада;

- начин доласка у позицију за ударац на гол (асистенција) - индивидуални напад, „друга лопта“, центаршут, повратна лопта, дубинско додавање;

- зоне из којих су упућивани удараци на гол 0 - 5 м, 5 - 11 м, 11 - 16 м и >16 м; 
- сегмент којим је изведен ударац - глава, лева нога, десна нога.

Поред успешних напада, у циљу дефинисања нападачке тактике, праћене су и варијабле које указују на оријентацију игре у ситуацијама када је тим у поседу лопте:

- укупно трајање поседа лопте на мечу, број долазака у посед лопте, трајање поседа лопте;

- број успешних додавања, проценат успешних додавања, брзина додавања (број прецизних додавања у јединици времена по оствареном поседу).

Анализи, претходно снимљених утакмица, приступило се тако што се формирао протокол посматрања (Carling et al., 2005). Протокол посматрања се користио за сваку утакмицу, за сваки тим посебно. Посматрањем утакмица, у посматрачком листу је забележен сваки успешан напад, односно акција која је завршена ударцем ка голу. Видео материјали су преузети са телевизијских канала Premium sport - HD, Bein sports - HD, Sky sport - HD и Premium Calco - HD.

\section{Обрада података}

Свака варијабла је обрађена стандардном дескриптивном статистиком (укупна и средња вредност, као и стандардна девијација). Разлике у расподели појединих тактичких показатеља, у оквиру једне групе, између такмичарске сезоне
2015/2016 и 2016/2017 процењиване су непараметријским Хи - квадрат тестом, а за испитивање разлика између два независна такмичења у појединим варијаблама коришећен је Ман - Витни $\mathrm{U}$ тест. Ниво статистичке значајности био је на $p<0.05$. Сви статистички тестови су били обрађени коришћењем SPSS 17.0 програма (SPSS INC Chicago, IL).

\section{РЕЗУЛТАТИ}

Резултати овог истраживања показали су да су тимови који су наступили у завршници такмичења у сезони 2016/2017 били нешто офанзивнији, што потврђује податак према коме је просечан број успешних напада био 11.5 у односу на претходну сезону - 9.5. Однос непрецизних, прецизних и ефикасних удараца ка голу је $48 \%$ - $41 \%$ - $11 \%$ у сезони $2015 / 2016$, и $49 \%$ - 38\% - $13 \%$ у сезони 2016/2017.

Посматрајући успешне нападе који су реализовани у одређеним временским интервалима, примећује се да је број таквих напада у сезонама 2015/16 и 2016/17 уједначен, међутим у сезони 2016/2017 нешто више напада реализовано је у уводним деловима првог и другог полувремена (Слика 1).

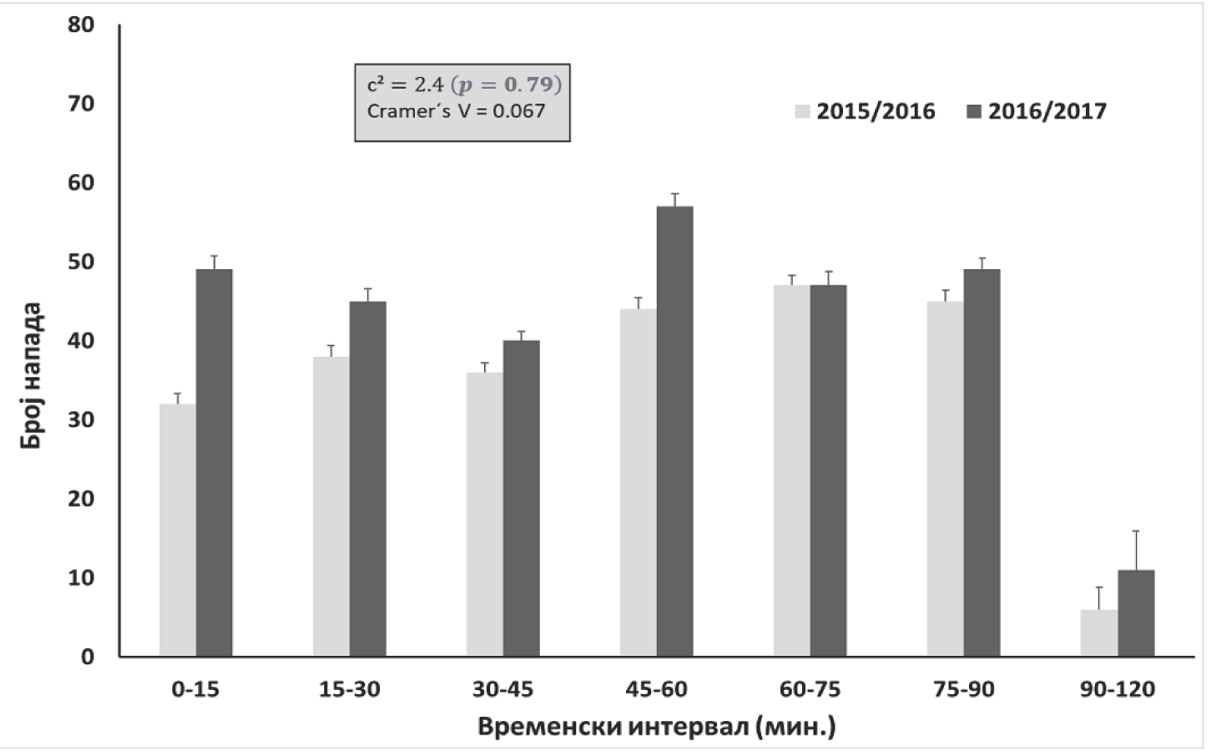

Слика 1. Број успешних напада у односу на временске интервале трајања утакмице у такмичењу Лиге шампиона (сезоне 2015/16 и 2016/17) 
Када је у питању врста напада, анализом је утврђено да је примена континуираних напада, контранапада и успешних акција након прекида игре сразмерно заступљена у обе сезоне (Табела 1). Нешто мањи проценат удараца ка голу након прекида, у сезони 2016/17, манифестовао се кроз повећање броја успешних напада из игре (континуирани напади и контранапади). Највише удараца ка голу је уследило након организације континуираних напада, а у вези са овим податком је просечно трајање успешних напада које је износило 13.9 секунди у сезони 2015/16, одно- сно 13.57 секунди у другој такмичарској сезони (Табела 2).

Успешне нападе у обе такмичарске сезоне, тимови су најчешће започињали из нападачке трећине терена, затим маневарског дела, а најмање успешних акција започето је из одбрамбене зоне (Табела 1). Поред тога, анализа показује да је у другој сезони (2016/2017) број напада започетих из нападачке зоне нешто већи у односу на прву сезону (46\% - 49\%), а са друге стране нешто мање нападачких акција започетих из маневарског простора (36\% - 32\%).

Табела 1. Зоне из којих су започете успешне акције, врсте реализованих успешних напада, зоне упућивања и сегменти којима су извођени удараци ка голу у такмичењу Лиге шампиона (сезоне 2015/16 и 2016/17).

\begin{tabular}{|c|c|c|c|c|c|}
\hline \multirow{2}{*}{ Зона почетка } & \multicolumn{2}{|c|}{$2015 / 2016$} & \multicolumn{2}{|c|}{$2016 / 2017$} & \multirow{2}{*}{ Chi Square } \\
\hline & Укупно & $\%$ & Укупно & $\%$ & \\
\hline Одбрана & 45 & 18 & 56 & 19 & $c^{2}=0.996$ \\
\hline Маневар & 89 & 36 & 95 & 32 & $p=608$ \\
\hline Напад & 114 & 46 & 147 & 49 & Cramer's V $=0.43$ \\
\hline \multicolumn{6}{|l|}{ Врста напада } \\
\hline Конт. напад & 138 & 56 & 173 & 58 & $c^{2}=1.320$ \\
\hline Контранапад & 58 & 23 & 74 & 25 & $p=0.517$ \\
\hline Прекид игра & 52 & 21 & 51 & 17 & Cramer's V $=0.049$ \\
\hline \multicolumn{6}{|l|}{ Зона шута } \\
\hline $0-5$ & 18 & 7 & 18 & 6 & $c^{2}=1.711$ \\
\hline $5-11$ & 87 & 35 & 119 & 40 & $p=635$ \\
\hline $11-16$ & 39 & 16 & 48 & 16 & Cramer's V $=0.056$ \\
\hline $16>$ & 103 & 42 & 113 & 38 & \\
\hline \multicolumn{6}{|l|}{ Ударац на гол } \\
\hline Глава & 50 & 20 & 58 & 19 & $c^{2}=0.101$ \\
\hline Нога (л) & 84 & 34 & 98 & 33 & $p=0.96$ \\
\hline Нога (д) & 114 & 46 & 142 & 48 & Cramer's V $=0.014$ \\
\hline
\end{tabular}

Резултати приказују да су ударци ка голу, у обе сезоне, најмање упућивани из зона 0 - 5м и 11 - 16м, као и да су играчи на посматраним утакмицама најчешће ударце изводили из зоне 5 - 11м и простора >16м (Табела 1). Међутим, у сезони 2015/16 проценат реализованих удараца из зоне 5 - 11м је мањи него из простора >16м, док је у сезони 2016/17 број удараца из зоне 5 - 11м већи у односу на ударце изван 16м. Доминирали су ударци изведени ногом, у највећем броју случајева је ударац реализован десном (46\% - 48\%), затим левом ногом $(34 \%-33 \%)$ и на крају су ударци главом (20\% - 19\%) (Табела 1).

Освајање „друге лопте“ и пресецање су најзаступљенији облици започињања успешних напада, а значајан број акција, које су се завршиле ударцем ка голу, је проистекао и након организације офанзивног прекида (Слика 2).

Анализа структуре напада, посматрано према ठроју играча који учествује и броју додавања у току успешне акције, показује да су тимови у обе сезоне успешне нападе изводили са 3 - 5 играча, при чему се размени најчешће 4 додавања пре него што се упути ударац ка голу (Табела 2).

Укупно трајање поседа лопте, на једној утакмици, је нешто веће у сезони 2016/17 и та разлика износи 45 секунди по мечу, поред тога, екипе су и за нијансу дуже имале лопту у поседу у другој сезони, просечно 16.8 секунди (Табела 2).

Динамика игре у обе сезоне је била подједнака, што потврђују резултати брзине додавања, али су екипе у другој сезони биле успешније приликом додавања између саиграча (Табела 2).

Резултати даље показују да се завршница успешних напада у највећој мери реализује након асистенција у виду центаршутева, затим након индивидуалних акција, дубинским додавањима, повратном лоптом и на крају након освојене „друге лопте“. Поред наведеног, занимљиво је и значајно повећање када су у питању асистенције центаршутевима и повратном лоптом у другој сезони (Слика 3). 


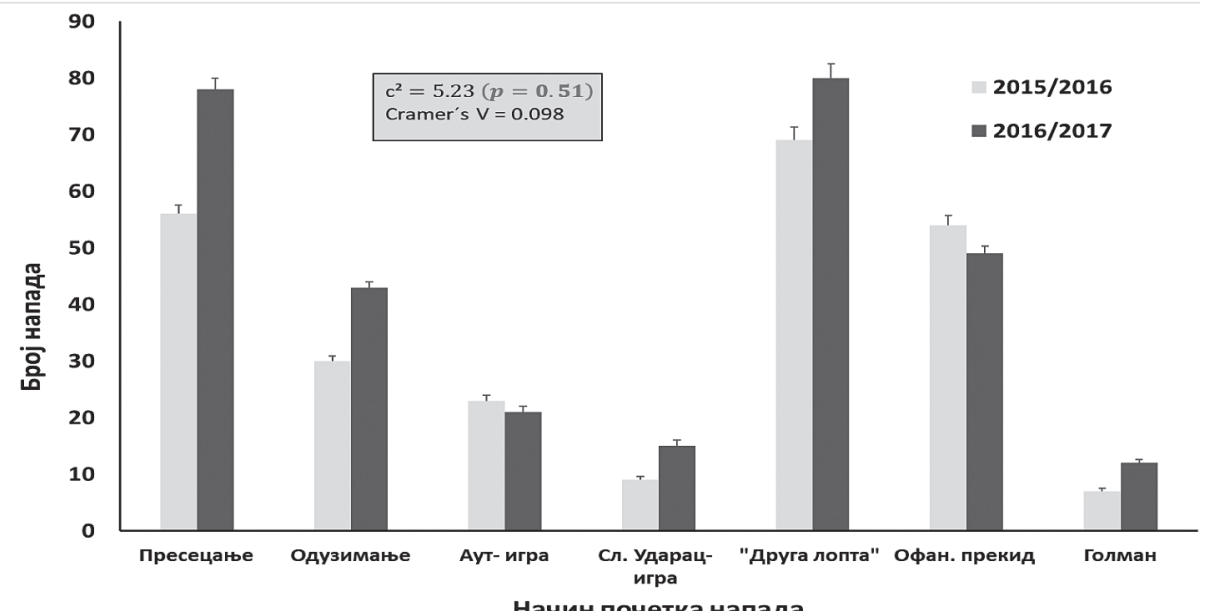

Слика 2. Начин започињања успешних напада у такмичењу Лиге шампиона (сезоне 2015/16 и 2016/17

Табела 2. Структура успешних напада, посед лопте и пас игра у такмичењу Лиге шампиона (сезоне 2015/16 и 2016/17)

\begin{tabular}{|c|c|c|c|c|c|}
\hline \multirow{2}{*}{ Успешни напади } & \multicolumn{2}{|c|}{$2015 / 2016$} & \multicolumn{2}{|c|}{$2016 / 2017$} & \multirow{2}{*}{$y$ mecm } \\
\hline & Средња вредност & Стдев & Средња вредност & Стдев & \\
\hline Број играча учесника & 4.22 & 1.14 & 4.01 & 1.01 & $p=0.406$ \\
\hline Број додавања & 4.62 & 2.15 & 4.23 & 1.61 & $p=0.510$ \\
\hline Tрајање & 13.9 & 5.89 & 13.57 & 4.17 & $p=0.869$ \\
\hline \multicolumn{6}{|l|}{ Посед лопте } \\
\hline Укупно (мин.) & 29.47 & 0.18 & 30.32 & 0.14 & $p=0.071$ \\
\hline Укупно поседа & 109 & 6.34 & 109.8 & 7.55 & $p=0.828$ \\
\hline Трајање поседа (сек.) & 16.5 & 2.57 & 16.8 & 2.24 & $p=0.433$ \\
\hline \multicolumn{6}{|l|}{ Пас игра } \\
\hline Успешна додавања & 471 & 92.5 & 479 & 70.78 & $p=0.337$ \\
\hline Успешна додавања (\%) & 84 & 2.8 & 86 & 2.3 & $p=0.013$ \\
\hline Брзина додавања & 16 & 1.02 & 16 & 0.86 & $p=0.804$ \\
\hline
\end{tabular}

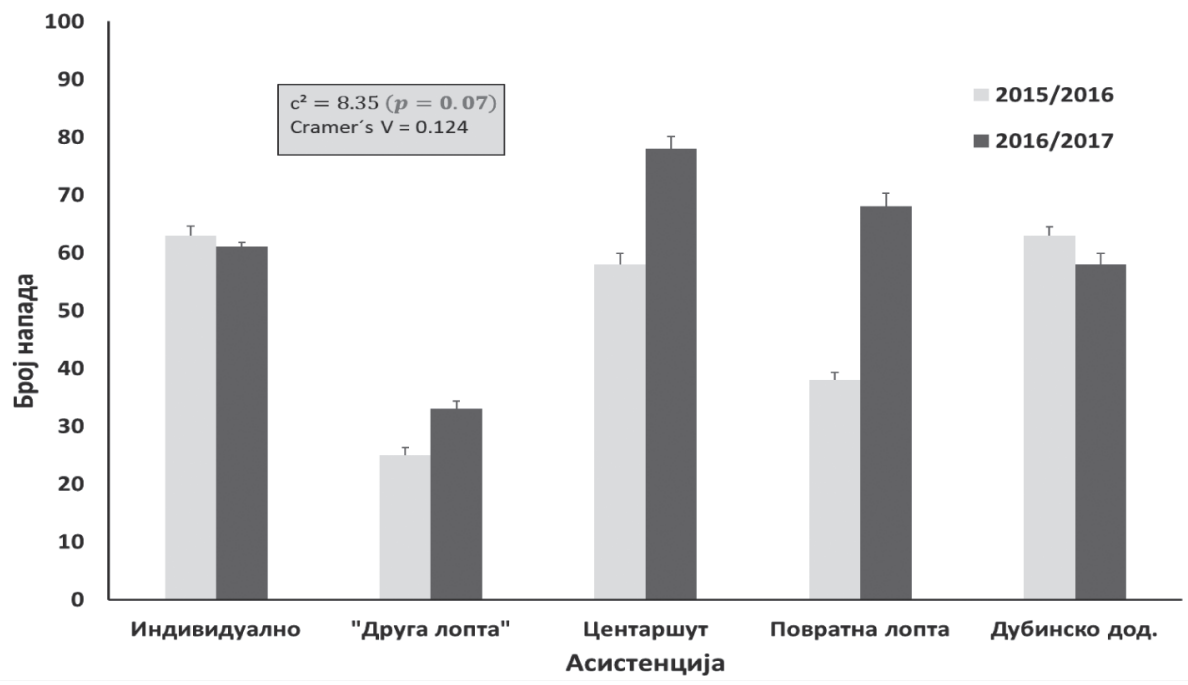

Слика 3. Број успешних акција у односу на начин доласка у позицију за ударац ка голу у такмичењу Лиге шампиона (сезоне 2015/16 и 2016/17) 


\section{ДИСКУСИЈА}

Резултати овог истраживања показали су да завршница такмичења Лиге шампиона захтева одређени ниво техничко-тактичког испољавања, узимајући у обзир чињеницу да нема значајних разлика у структури успешних напада екипа које су се пласирале у четвртфинале овог такмичења у две такмичарске сезоне. Међутим, издвојили су се поједини техничко-тактички елементи игре који се у једној мери разликују и на тај начин указују на одређене иновације у припреми екипа за завршницу такмичења.

Реализација успешних напада у односу на временске интервале трајања, показала је да нема разлика у динамици игре између две такмичарске сезоне, међутим примећује се ипак да су првих 15 минута оба полувремена били активнији периоди у сезони 2016/2017. Обе такмичарске сезоне карактерише већи број удараца на гол у другом полувремену, што је и генерално случај и на осталим такмичењима (Sgro et al., 2015; Liu et al., 2016). Интересантно је да је у другој сезони највише удараца на гол упућено управо у уводним деловима утакмице, што се може довести у везу са подацима према којима тим који први поведе у 70.9\% случајева долази до победе (Michaildis et al., 2013).

Према појединим анализама долазак у посед лопте дубоко на половини противника један је од фактора који директно утиче на успех у савременом фудбалу (Mackenzie \& Cushion, 2013; Almeida et al., 2014; Јанковић и сар., 2016). Резултати овог истраживања показали су да екипе, које су се дефинитивно самим пласманом у завршницу такмичења издвојиле по квалитету, теже да применом високог пресинга одузму лопту противнику што ближе његовом голу и на тај начин нападну „несређену“ одбрану противника. Незнатно већи проценат започетих напада из нападачке трећине терена, у сезони 2016/2017, је између осталог и утицао на већу ефикасност успешних напада у односу на такмичарску сезону 2015/2016.

Примена континуираног напада, према резултатима овог истраживања, представља доминантан облик организације офанзивних акција. Ако се узме у обзир податак према којем је примена континуираног напада директно у вези са позитивним резултатом (Леонтијевић и сар., 2015), може се рећи да је за пласман у завршницу такмичења потребно тактичко опредељење у игри ко- јим се пас игром и поседом лопте долази до ударца на гол противника. За овакав тактички план неопходни су играчи који су пре свега технички оспособљени за такав начин игре. Према томе, тимови који своје офанзивне акције базирају искључиво на директној игри (контранапад) или се ослањају на прекид игру, не могу у континуитету да постижу добре резултате. Међутим, оваква тврдња може се испитати у неком од следећих истраживања, ако узмемо у обзир чињеницу да су ово елиминационе утакмице, па је самим тим и значај далеко већи, „опрезније“ се игра, екипе једноставно мање ризикују у игри, теже да пре свега обезбеде свој гол, мање губе лопту у фази започињања напада итд.

Квалитет у игри применом континуираног напада, између осталог, може се анализирати ефикасношћу у поседу лопте који се опет манифестује кроз успешност у додавању лопте. Такмичарска сезона 2016/2017 је била ефикаснија у односу на претходну (већи број голова), чему је вероватно допринео податак према коме су тимови у тој сезони лопту имали у поседу дуже за 45 секунди на мечу. Поред тога, другу сезону карактерише значајно већа успешност у пас игри ( $\mathrm{p}=0.013)$, док је брзина кретања лопте приликом додавања била подједнака. Дакле, намеће се закључак да је за постизање резултата у фудбалу, на највишем нивоу, неопходна техничка припрема играча за игру са што већом успешности у додавању и игри под притиском. Резултати истраживања која су анализирала такмичења различитог нивоа (националне лиге), показују такође да су трајање поседа лопте, успешност у пас игри и брзина кретања лопте приликом додавања, основни индикатори успешности (Bekris \& Gioldasis, 2014; Леонтијевић и сар., 2015; Barreira et al., 2016)

Долазак у посед лопте ближе голу противника, примена пресецања лопте и освајања „друге лопте“, у започињању акција које се завршавају ударцем на гол, указују на примену пресинг игре високо на почетак напада противника која је за нијансу била заступљенија у такмичарској сезони 2016/2017. Такође удаљеност приликом ударца на гол је податак који корелира са позитивним резулататом и ефикасношћу самог ударца (Michailidis et al, 2013; Liu et al., 2015b), па је нешто већи број удараца из зоне 5 - 11 метара у сезони 2016/2017 утицао на већи број постигнутих голова. Међутим, интересантан је податак према којем је 
све више удараца на гол после додавања са бока (центаршут) и повратних додавања, ако се узме у обзир податак према којем број центаршутава на утакмици негативно корелира са успехом на утакмици (Liu et al., 2015b; Liu et al., 2016).

\section{ЗАКЉУЧАК}

Анализа завршнице такмичења Лиге шампиона у сезонама 2015/2016 и 2016/2017 показала је да за овај ниво такмичења постоји јасно дефинисана структура нападачких акција које се завршавају ударцем на гол. Примена континуираних напада, висок проценат успешности у пас игри са брзом дистрибуцијом лопте, посебно у нападачкој трећини терена представља доминантан облик реализације успешних напада. Такође, може се закључити, на основу ипак одређених разлика, да је тенденција у офанзивној тактици ка игри преко бочних позиција, ка игри коју спроводе играчи беспрекорне техничке обучености што утиче на прецизност у додавању лопте и на крају на ефикасност завршног додавања и ударца на гол. Поред тога, повећава се број напада започетих у нападачкој трећини терена, дакле примена високог пресинга на почетак напада противника постаје све учесталије опреде-

\section{ЛИТЕРАТУРА:}

1. Almeida, C.H., Ferreira, A.P., \& Volossovitch, A. (2014). Effects of match location, match status and quality of opposition on reagaining possession in UEFA Champions League. Journal of Human Kinetics, 41(1), 203 - 214.

2. Barreira, J., Vendite., C., \& Vendite L.L. (2016). Analysis of shots and passing sequence of a soccer team and its opponents during 2014 Brazilian Championship. International Journal of Sports Science, 6(4), 163 - 167.

3. Bekris, E., \& Gioldasis, A. (2014). Winners and losers in top level soccer. How do they differ? Journal of Physical Education and Sport, 14(3), 398 - 405.

4. Carling, C., Williams, A.M., Reilly, T. (2005). Handbook of soccer matches analysis. A systematic approach to improving performance. Routledge, London.

5. Castellano, J., Casamichana, D., \& Lago, C. (2012). The use of match statistics that discriminate be- љење у дефанзивној организацији.

У правцу детаљније анализе и прецизнијег откривања механизама игре, потребно је у будућим истраживањима посеठно сагледати структуру континуираних напада, контранапада и акција реализованих након прекида игре. Такође, упоредном анализом, елиминационих утакмица и групне фазе такмичења, истражити да ли и којој мери важност утакмице утиче на тактички план игре. Наравно, анализа сваке наредне такмичарске сезоне само ће утврдити одређене стандарде у офанзивној тактици фудбала на највишем нивоу, али и указивати на актуелне тендеције развоја и унапређења.

Вредност овакве врсте анализа из простора тактике фудбала огледа се у јасним смерницама када је у питању припрема једне фудбалске екипе која претендује на висок пласман у такмичењу Лиге шампиона. Дакле, прецизно су дефинисани неопходни параметри игре, односно, одређен је критеријум захтева за највиши ниво компетиције. Са друге стране, теоријска вредност оваквог приступа у анализирању такмичарске активности у фудбалу је дефинисање актуелних захтева у тактици фудбала на највишем нивоу и предвиђање евентуалних тенденција развоја у наредном периоду.

tween successful and unsuccessful soccer teams. Journal of Human Kinetics, 31, 139 - 147.

6. Јанковић, А., Леонтијевић, Б., Мићовић, Б. (2009). Тенденције развоја тактике игре кроз анализу успешних напада на XVI, XVII и XVIII Светском првенству у фудбалу. У: Копривица В. и Јухас И. (ур.). Зборник радова са: Теоријски, метиодолошки и метиоячики асиектии итакмичеюа и йрийреме сйорйисйа, (115 - 120). Београд: ФСФВ.

7. Јанковић, А., Леонтијевић, Б., и Томић, Л. (2016). Игра у нападу фудбалских тимова који наступају у Лиги шампиона и Супер лиги Србије. Физичка кулииура, 70(1), 80 - 87.

8. Lago - Penas, C., Lago - Ballesteros, J., Dellal, A. \& Gomez, M. (2010). Game - related statistics that discriminated winning, drawing and losing teams from the Spanish soccer league. Journal of Sports Science and Medicine, 9, 288 - 293. 
9. Леонтијевић, Б., Јанковић, А., и Ћосић, Н. (2015). Упоредна анализа тактичког испољавања фудбалера Партизана на утакмицама у европским такмичењима и Супер лиги Србије. У Касум Г. и Мудрић М. (ур.). Зборник радова са: Ефекиии ирримене физичке актиивносиии на анйройолошки стиайус gеце, омлаgине и оgраслих, (443 - 450). Београд: ФСФВ.

10. Liu, H., Gomez, M.A. (2014). Relationships between match performance indicators and match outcome in 2014 Brazil FIFA World Cup. Conference: VIII Congreso Internacional de la Asociacion Espanola de Ciencias del Deporte. Spain.

11. Liu, H., Yi, Q., Gimenez, J.V., Gomez, M.A., \& Lago - Penas, C. (2015a). Performance profiles of football teams in the UEFA Champions League considering situational efficiency. International Jorunal of Performance Analysis in Sport, 15, 371 - 390.

12. Liu. H., Gomez., M.A., Lago - Penas, C., \& Sampaio, J. (2015b). Match statistics related to winning in the group stage of 2014 Brazil FIFA World Cup. Journal of Sports Sciences, 33(12), 1205 - 1213.

13. Liu, H., Gomez, M.A., Goncalves, B., \& Sampaio, J. (2016). Tehnical performance and match to match variation in elite football teams. Journal of Sports Sciences, 34(6), 509 - 518.

14. Mackenzie, R., Cushion, C. (2013). Performance analysis in football: A critical review and implica- tions for future research. Journal of Sports Sciences, 31(3), 639 - 676.

15. McGarry, T., Anderson, D. I., Wallace, S. A., Hughes, M. D., \& Franks, I. M. (2002). Sport competition as a dynamical selforganizing system. Journal of Sports Sciences, 20(10), 771 - 781.

16. Michaildis, Y., Michaildis, C., Primpa, E. (2013). Analysis of goals scored in European Championship 2012. Journal of Human Sport \& Exercise, 8(2), $367-375$.

17. Mitrotasios, M., \& Armatas, V. (2014). Analysis of goal scoring patterns in the 2012 European Football Championship. The Sport Journal. Available at http://thesportjournal.org/article/analysis-of-goal-scoring-patterns-in-the-2012-european-football-championship/.

18. Sarmento, H., Marcelino, R., Anguera, M. T., Campanico, J., Matos, N., \& Leitao, J. C. (2014). Match analysis in football: A systematic rewiew. Journal of Sports Sciences, 32(20), 1831 - 1843.

19. Sgro, F., Barresi, M., \& Lipoma, M. (2015). The analysis of discriminant factors related to team match performance in the 2012 European Football Championship. Journal of Physical Education and Sport, 15(3), 460 - 467.

20. Wallace, J.K., \& Norton, K.I. (2014). Evolution of World Cup soccer final games 1966 - 2010. Journal of Science and Medicine in Sport, 17(2), 223 - 228.

\title{
ANGRIFFSTAKTIK VON FUBBALLMANNSCHAFTEN IN DER ENDPHASE DER CHAMPIONS-LEAGUE IN DEN SAISONS 2015/2016 UND 2016/2017
}

\begin{abstract}
Zusammenfassung
Ziel dieser Arbeit ist es, durch eine Analyse der Wettbewerbsaktivitäten Charakteristiken der Angriffstechnik von Teams zu entdecken, die in der Endphase der Champions-League spielen, sowie durch eine parallelle Analyse der gleichen Meisterschaft in zwei Wettbewerbssaisons auf eventuelle Tendenzen in der Taktikvorbereitung für die Endphase der Meisterschaft hinzuweisen. Die Analyse umfasste das Viertelfinale, Halbfinale und die Finalspiele in den Saisons 2015/2016 und 2016/2017, also je 13 Fußballspiele in beiden Saisons. Das taktische Vorgehen wurde durch Verfolgung von Variablen analysiert, die Beginn, Realisierung und Abschluss von erfolgreichen Angriffen beschreiben, aber auch der insgesamten Charakteristiken des Spiels, wenn das Team im Besitz des Balls ist (Umfang, Erfolg und Geschwindigkeit im Zuspielen des Balles). Die Ergebnisse dieser Untersuchung weisen darauf hin, dass es keine bedeutenden Unterschiede in der taktischen Vorgehensweise der Teams gibt, die in der Endphase der Meisterschaft in zwei Wettbewerbssaisons spielen. Es dominiert die Anwendung von kontinuierlichen Angriffen, die mit Abschneiden und Eroberung des „Zweiten Balles“ in der gegnerischen Spielhälfte begonnen werden; das finale Zuspielen bezieht sich in größtem Maße auf Flankenstoß oder Rückpass aus seitlichen Positionen. Ein bedeutender Unterschied wurde nur in der Effizienz beim Passspiel entdeckt, der bedeutend größer in der Saison 2016/2017 (p=0.013) war und teilweise im längeren Ballbesitz ebenfalls in der Saison 2016/2017. Der Wert dieser Art von Analyse aus dem Bereich der Fußballtaktik spiegelt sich in der Definierung der Kriterien für die Erzielung von Ergebnissen auf höchster Ebene, aber auch in der Prädiktion eventueller Tendenzen in der Entwicklung von offensiven Fußballtaktiken.
\end{abstract}

Schlüsselwörter: FUßBALL / WETTBEWERBSAKTIVITÄT / SPIELANALYSE / ERFOLGREICHE ANGRIFFE / PASSSPIEL

Примљен: 25. 09. 2017.

Прихваћен: 15. 11.2017. 